\title{
ANALISE DESCRITIVA DA CABECEIRA DE VEREDA DO CÓRREGO BURITIZAL NA ÁREA URBANA DE ITUIUTABA. MG.
}

\author{
Bruno Henrique dos Santos Batista ${ }^{1}$ \\ Vanessa Santos Pereira ${ }^{2}$ \\ Katia Gisele Oliveira Pereira
}

\begin{abstract}
RESUMO
O presente trabalho se propõe a analisar os impactos ambientais que ocorrem na cabeceira de vereda do córrego Buritizal, localizada na cidade de Ituiutaba - MG. O objetivo deste trabalho é mostrar que os impactos ambientais que ocorrem com a ausência de gestão ambiental, abandono da área e com a urbanização descontrolada em áreas de APP (Área de Proteção Permanente) podem evoluir. A vinda da universidade (UFU) para esta região sul da cidade e a valorização das terras ao redor desta são fatores que tendem a aumentar os impactos ambientais na área ao longo dos anos. A partir das bibliografias especializadas de Christofoletti, (1981), Pruski, Brandão e Silva, (2004), Bigarella e Suguio, (1979), registros fotográficos em campo e imagens de satélite da área foram feitas análises das condições ambientais em que se encontra a vereda. Todos esses recursos e referências foram suficientes para apresentar o resultado de que as obras de infraestrutura realizadas pela Prefeitura de Ituiutaba - MG são as responsáveis pelos impactos ambientais presentes em toda a extensão do córrego do Buritizal.
\end{abstract}

Palavras-chave: Impacto ambiental, infraestrutura, córrego, vereda.

\section{DESCRIPTIVE ANALYSIS OF VEREDA BURITIZAL STREAM OF HEAD IN URBAN AREA ITUIUTABA MG.}

\section{SUMMARY}

The present paper aims to analyze the environmental impacts that occur in the Buritizal stream headwater of drain, located in Ituiutaba - MG. The objective of this paper is to show that the environmental impacts that occur in the absence of environmental management, area abandonment and uncontrolled urbanization in areas of APP (Area of Permanent Protection) may increase. The coming of the Federal University of Uberlândia for the city's south region and the appreciation of the land around the university are factors that tend to increase the environmental impacts in the region over the years. From the specialized bibliographies Christofoletti, (1981), Pruski, Brandão and Silva (2004), Bigarella and Suguio, (1979), field photographic records and satellite images of the area were made analysis of the environmental conditions in which is the path. All of these features and references were sufficient to present as result that the works of infrastructure carried out by Ituiutaba Prefecture are the responsible for the environmental impacts throughout the length of the Buritizal stream.

Key words : Environmental, infrastructure, stream, path.

\footnotetext{
${ }^{1}$ Graduandos do Curso de Geografia, Faculdade de Ciências Integradas do Pontal/Universidade Federal de Uberlândia. bruno00eu@hotmail.com; vanessa.seratna@gmail.com

2 Professora do Curso de Geografia, Faculdade de Ciências Integradas do Pontal/Universidade Federal de Uberlândia. Katia_gisele@pontal.ufu.br
} 


\section{ANÁLISIS DESCRIPTIVO DE VEREDA BURITIZAL STREAM DE CABEZA EN ZONA URBANA ITUIUTABA MG.}

\begin{abstract}
RESUMEN
Este estudio tiene como objetivo analizar los impactos ambientales que se producen en el camino de la cabeza de la corriente Buritizal, situada en Ituiutaba - MG. El objetivo de este trabajo es mostrar que los impactos ambientales que se producen en ausencia de la gestión ambiental, el área de abandono y la urbanización descontrolada en áreas de APP (Área de Protección Permanente) pueden desarrollar. La venida de la Universidad (UFU) para esta región sur de la ciudad y de la apreciación de la tierra alrededor de este, son factores que tienden a aumentar los impactos ambientales en la zona en los últimos años. A partir de las bibliografías especializadas de Christofoletti, (1981), Pruski, Brandão y Silva (2004), Bigarella y Suguio, (1979), registros fotográficos en los análisis de imágenes de satélite de campo y el área se hicieron de las condiciones ambientales en las que es el camino (río). Todas estas características y referencias eran suficiente para presentar el resultado de que las obras de infraestructura realizadas por Ituiutaba Prefecture - MG son responsables de los impactos ambientales presentes en toda la longitud de la corriente Buritizal.
\end{abstract}

Palabras clave: impacto ambiental, de infraestructura, de flujo, de trayectoria.

\section{INTRODUÇÃO}

O uso do solo desordenado presente nos espaços urbanos geram ambientes que colocam em risco o meio ambiente, as pessoas e demais seres vivos que vivem em seu entorno:

\begin{abstract}
"Nas três últimas décadas tem-se observado uma intensificação de pressões exercidas sobre os ecossistemas florestais no território brasileiro, principalmente nas áreas de Cerrado, que nesse período viu um grande avanço da agropecuária sobre suas áreas naturais. " (COSTA, 2011).
\end{abstract}

Este ensaio tem como intuito verificar os impactos ambientais causados pela instalação de galerias de drenagem pluvial e o seu lançamento na cabeceira do Córrego Buritizal, localizado na Cidade de Ituiutaba, MG.

O recorte espacial escolhido para a pesquisa era uma vereda, Ferreira, (2008), conceitua vereda em seu artigo:

\footnotetext{
"Genericamente as veredas se configuram como vales rasos, com vertentes côncavas suaves cobertas por solos arenosos e fundo planos preenchidos por solos argilosos, frequentemente turfosos, com elevada concentração de restos vegetais em decomposição. Em toda a extensão das veredas o lençol freático aflora ou está muito próximo da superfície. As veredas são, portanto, áreas de exudação do lençol freático e, por isto mesmo, em todas as suas variações tipológicas, são nascentes muito suscetíveis de se degradarem rapidamente sob intervenção humana predatória. (FERREIRA, 2008).
} 
No entorno da área escolhida para a realização da pesquisa encontrasse os bairros Tupã (margem direita) e o Gerson Baduy (margem esquerda), local de grande importância por ser um local de drenagem dos novos bairros e do parque do Goiabal, que fica próximo ao novo campus da universidade (UFU - Universidade Federal de Uberlândia).

A ocupação do bairro Tupã se deu com a relocação das famílias, que moravam nas imediações do córrego São José, devido a obras de embelezamento urbano, canalização do córrego, no perímetro urbano e uma área de lazer para a população. Este bairro periférico possui uma população de baixa renda, ocupação anterior à chegada da universidade (UFU).

O bairro Gerson Baduy apresenta um padrão diferente dos bairros préexistentes a chegada da UFU, que encontra em partes na área antes ocupada pela vereda, sua instalação foi posterior a chegada da universidade (UFU).

O Parque Municipal do Goiabal é considerado uma unidade de conservação e uso sustentável, com o intuito de preservar o ecossistema natural, para pesquisas científicas, realização de atividades de educação ambiental e de lazer, (COSTA, 2011).

Tais fatores analisados com presentes na expansão urbana da cidade de Ituiutaba foram relevantes na produção deste artigo, como a valorização imobiliária do bairro Tupã e a criação do bairro Gerson Baduy. Este processo de ocupação está se dando de forma acelerada a fim de suprir uma crescente demanda por expansão da área urbana criada com a instalação da universidade (UFU) já em 2007.

A área entre os bairros tem características de uma vereda, com topografia suave, solos mal drenados, com a presença de várias nascentes espalhadas em modos aleatórios e lençol freático aflorando, tendo entre suas características principais a presença de Buritis (Maurítia flexuosa). Deste modo a vereda não deveria ser utilizada para a drenagem dos bairros ao redor da mesma, como também dos novos bairros mais distantes e fora da bacia. Estes bairros foram instalados depois da construção da universidade e exigiam a condução da água pluvial para os vales, com drenos dentro do canal. Esta prática levou os órgãos públicos a instalarem infraestruturas básicas, levando a construção de vários dutos de captação de águas pluviais desses bairros e que estão sendo lançados na cabeceira do córrego Buritizal em Ituiutaba, MG. Assim, tem-se a necessidade de 
descrever e analisar tais práticas com a finalidade de trazer a público como é de fato e como pode ser modificada a visão do uso dos recursos naturais urbanos e políticas públicas que valorizem os ambientes e suas funções, como aponta Beltrame (1994) sobre a degradação ambiental, "A degradação desenfreada dos recursos naturais renováveis nos dias de hoje, é um processo que deve ser analisado e contido com eficiência e rapidez." (BELTRAME,1994).

É de conhecimento comum os inúmeros problemas que vem sendo registrados devido à má conservação dos ambientes de fundo de vales, atingindo em sua maioria as cidades grandes e médias, como mostra o artigo de Travassos e Schult (2013), sobre os fundos de vales urbanos na cidade de São Paulo.

Com o conhecimento dos problemas, pouco se tem feito para a conservação de mananciais de águas nas áreas urbanas e rurais, o que acaba agravando o problema de abastecimento de água, ocupação de encostas com declividades acima de $45^{\circ}$ e das áreas marginais, contaminação do solo devido ao descarte de lixo urbana de forma indevida, entre outros impactos devido à falta de planejamento.

\section{OBJETIVOS}

Este trabalho tem como objetivo geral analisar os impactos ambientais causados com a instalação das galerias de drenagem pluvial e do lançamento dessa água na cabeceira da vereda do córrego Buritizal, que se localiza na cidade de Ituiutaba, MG. Assim será necessário caracterizar o meio físico, biológico e socioeconômico e, levantar os impactos ambientais provocados pela urbanização e suas consequências para o córrego Buritizal, como objetivos específicos a serem atingidos.

\section{METODOLOGIA}

Para o desenvolvimento desta pesquisa foram elaboradas etapas metodológicas com a finalidade de conduzir o desenvolvimento da pesquisa (Figura 2).

As etapas metodológicas são levantamento bibliográfico que cumpre o intuito de estruturar na literatura os principais conceitos a estruturarem a pesquisa 
de campo e as análises, os trabalhos de campo nos quais serão feitas as observações, medidas e acompanhamento evolutivo dos processos fluviais e erosivos e a etapa de tratamento dos dados que se dará em laboratório. Segue a descrição de cada uma das etapas.

Foram levantadas referências da literatura produzida pela Geografia Física presente nos artigos publicados com pesquisas na cidade de Ituiutaba-MG, da área de clima, solo, água, vegetação e os impactos ambientais relacionado ao lançamento de águas pluviais em córregos, geomorfologia fluvial, escoamento superficial, geografia do cerrado, diagnósticos do meio físico de bacias e de infraestruturas urbanas, e uma das leis ambientais federais que protegem os mananciais urbanos para uma melhor compreensão sobre leis referentes a esses tipos de drenagens pluviais.

Figura 1 - Orientação metodológica das etapas de trabalho da investigação.

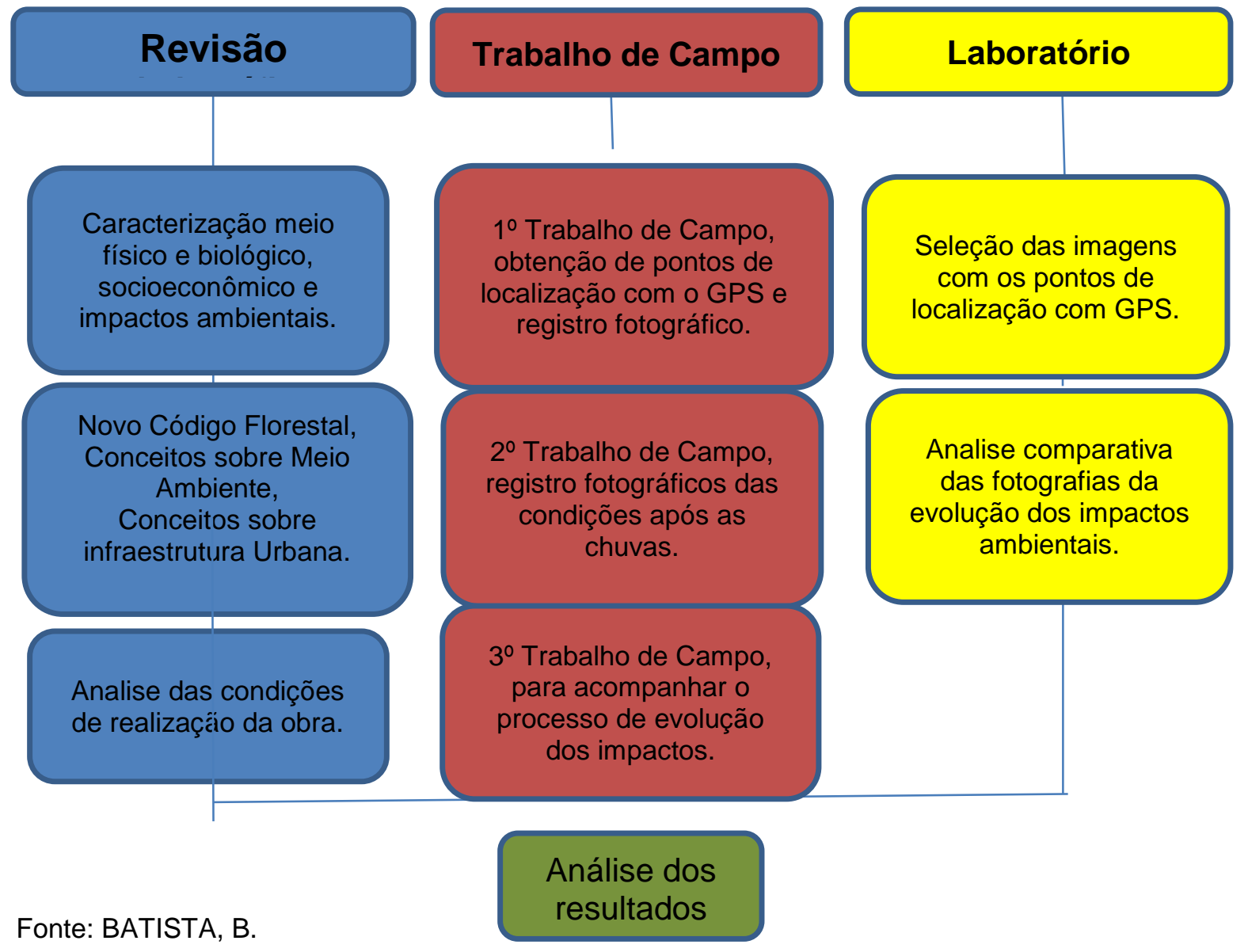

No campo foram utilizados os equipamentos de GPS (global positioning system) Garmin Legend H, máquina fotográfica Nikon Coopix L820. O uso do GPS teve como finalidade registrar a cada 5 (Cinco) metros um ponto de localização, tendo início na margem do córrego Buritizal até sua extremidade, circulando a obra 
de canalização da nascente, desta forma foram gerados dados de altimetria e localização geográfica dos pontos.

Com estes dados foi possível georreferências e transferir os dados de campo para as imagens de satélite da área já registradas. Da mesma forma, todos os perfis e pontos de coleta de dado foram levantados em campo com o uso do GPS.

Com a máquina fotográfica, foram registradas fotos dos mesmos pontos retirados pelo GPS, a fim de acompanhar a evolução do escavamento do talvegue devido a sua reativação provocada pela saída de água das canaletas instaladas dentro da vereda.

Com as imagens Rapideyes e a conferência dos pontos de amostragens visualizados no Google Earth, foram selecionadas as imagens com as coordenadas geográficas tiradas em campo, uma de declividade do fluxo de água da vertente até o principal curso d'agua, onde o córrego Buritizal desagua e, uma segunda da cabeceira do córrego para o entendimento do padrão topográfico da cabeceira.

Em seguida foram analisadas as fotos para acompanhar a evolução dos impactos ambientais gerados após as chuvas com o lançamento das águas pluviais na calha do Córrego Buritizal e se há o comprimento do Novo Código Ambiental, Lei no $12.651 / 2012$.

\section{RESULTADOS}

Os estudos teóricos, as atividades práticas em laboratório e trabalhos de campos realizados para a produção deste artigo foram fundamentais para a identificação dos impactos ambientais em várias vertentes com relação às obras realizadas na cabeceira do córrego Buritizal, localizado na cidade de Ituiutaba, MG.

O município de Ituiutaba se encontra na região central da microrregião do Triângulo Mineiro e Alto Paranaíba, no Estado de Minas Gerais. O talvegue dos principais rios como o rio Tijuco e rio da Prata estão assentados sobre a litologia de basaltos da Formação Serra Geral que formam lajes que sustentam os arenitos do Grupo Bauru como a Formação Rio do Peixe (Adamantina) e os arenitos da Formação Marília. A topografia varia de $750 \mathrm{~m}$ no topo dos relevos residuais à $400 \mathrm{~m}$ próxima a foz do rio Tijuco, conforme figura 2. 


\section{Periódica Eletrânica \\ Fórum Ambiental}

da Alta Paulista

Volume 11, Número 06, 2015

Planejamento e Gestão dos Recursos Hídricos

O relevo segundo Baccaro (2006) corresponde a áreas de relevo medianamente dissecadas, com vertentes convexas nos topos e côncavas no fundo de vales. Nas cabeceiras de drenagem de todo o município predominam as veredas que são segundo Boaventura (1978) apud Ferreira (2005).

"Configuradas por vales rasos, com vertentes côncavas suaves cobertas por solos arenosos e fundo plano preenchidos por solos argilosos, frequentemente turfoso, ou com elevada concentração de restos vegetais em decomposição. O lençol freático aflora em toda a sua extensão, ou está muito próximo da superfície. São nascentes susceptíveis de se dragarem rapidamente sob qualquer interferência antrópica Boaventura". (BOAVENTURA,1978. apud. FERREIRA, 2005.)

Figura 2 - Localização e topografia do Município de Ituiutaba. MG.

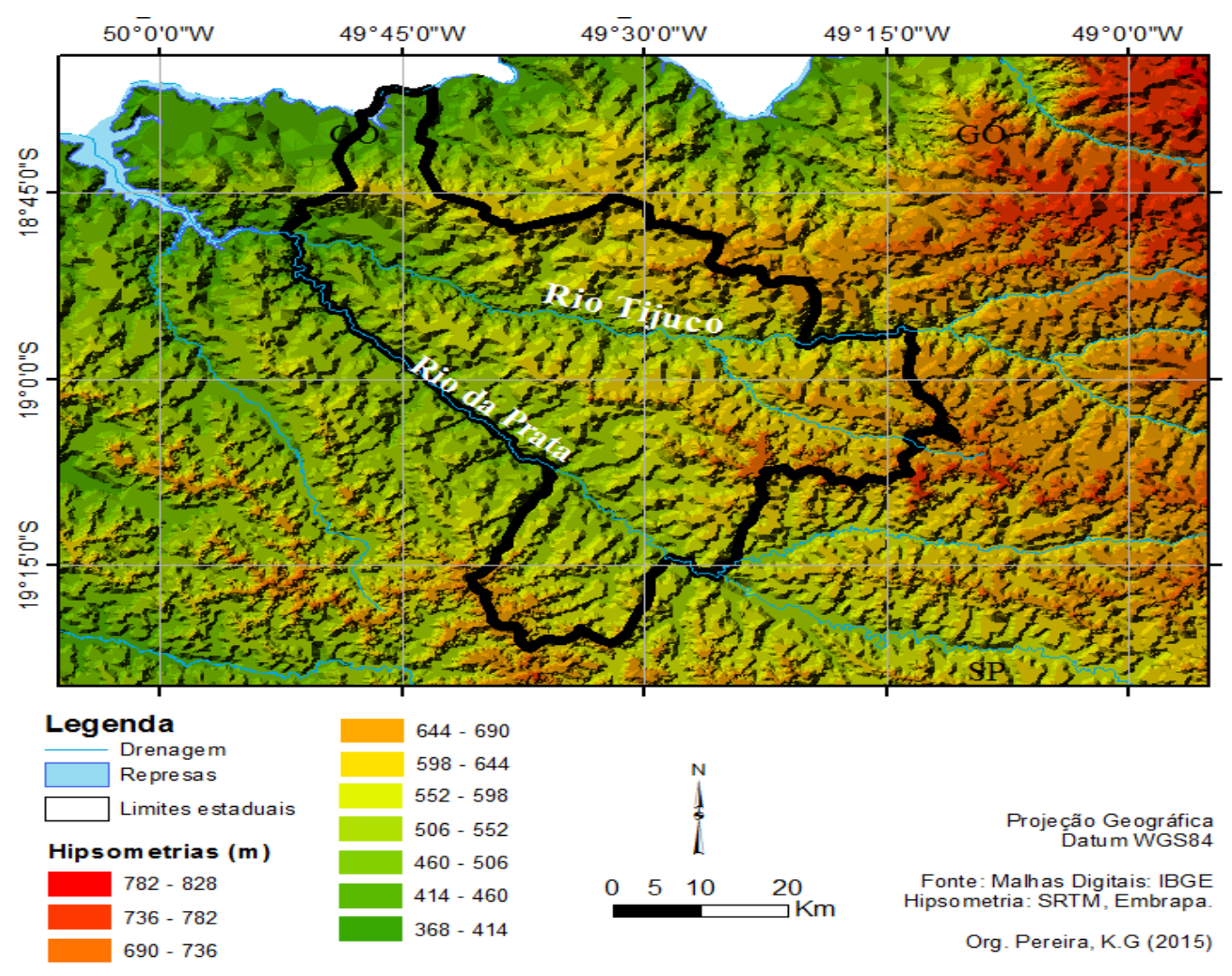

Fonte: IBGE, 1983.

Segundo Ferreira (2005), estes ambientes necessitam de pesquisas para servir de alerta para a necessidade urgente de preservação. Dentre suas funções, as veredas funcionam como um filtro, regulando o fluxo de água, sedimentos e nutrientes, entre outros terrenos mais altos da bacia hidrográfica e o ecossistema aquático, pode ainda, servir de refúgio para a fauna e a flora. A regulagem determina a contribuição de água para os cursos d'água, cuja área saturada se expande ou 


\section{Periódica Eletrânica

contrai dependendo das condições de umidade depositada, ou seja, das precipitações e da capacidade de retenção e escoamento do solo. Seu aspecto brejoso não foi valorizado pelo processo de ocupação do Cerrado, por isso vistas como perdidas. São comuns em veredas serem entulhos de desmatamento, lagoas para irrigação, em áreas urbanas não são muito diferente. O que leva a crer que não há cumprimento da legislação brasileira emitida por órgãos competentes com a função de gerir e fiscalizar o cumprimento da lei, fazendo vistas grossas no que se refere à preservação das veredas. Segundo LIMA (1991) apud Ferreira (2005).

Figura 3 - Localização da Bacia do Córrego Buritizal. Ituiutaba. MG.

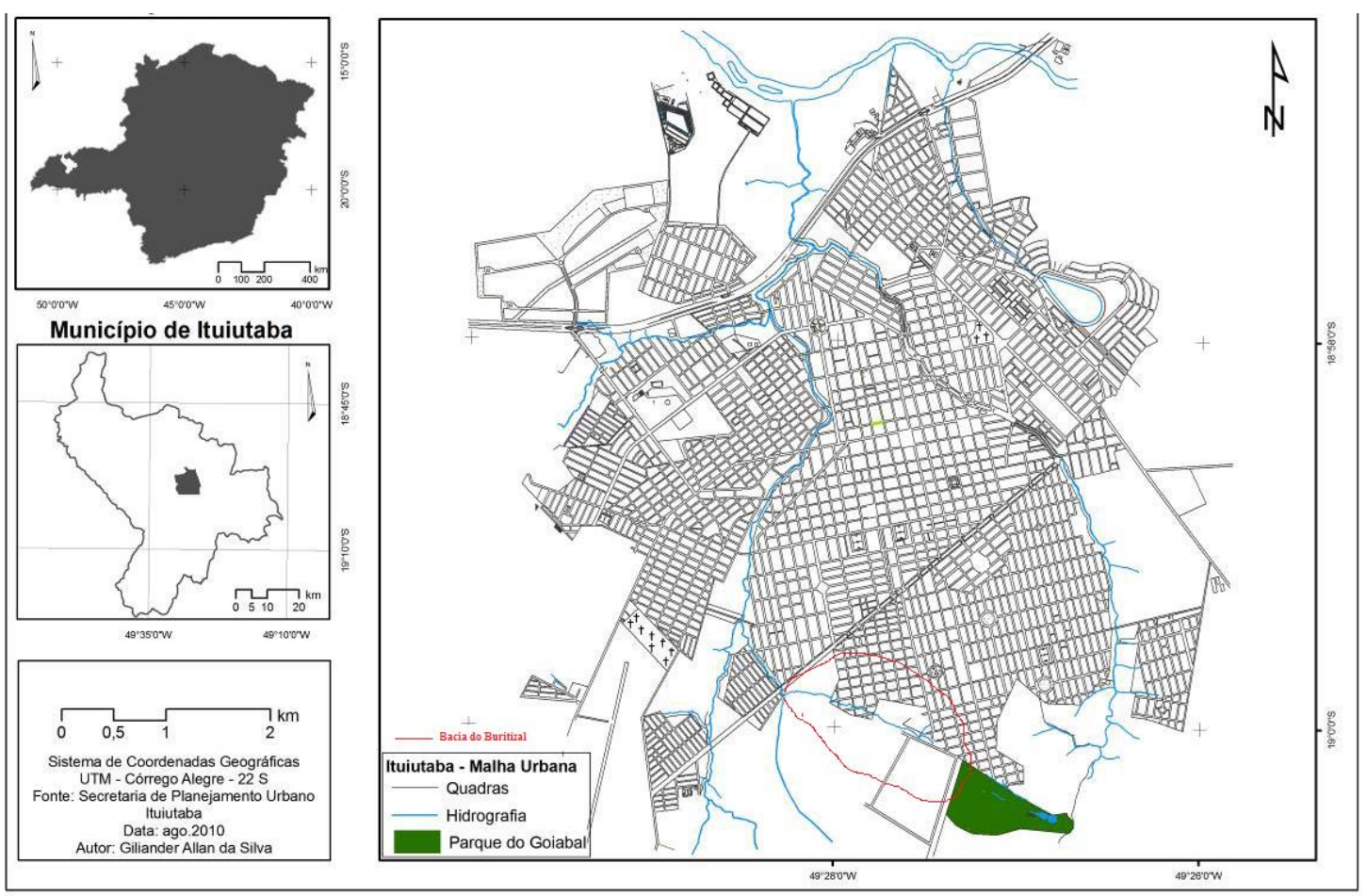

Fonte: Adaptação de (COSTA, 2011)

O clima alternado entre verão chuvoso e inverno seco, corresponde aos sistemas intertropicais, com circulação alternada. O inverno seco tem duração aproximada de abril a setembro com $10 \%$ das chuvas anuais e o verão úmido que tem duração aproximada de outubro a março correspondendo aos $90 \%$ restante das chuvas anuais. A média de temperatura anual ocorre entre 20 a $22^{\circ} \mathrm{C}$, com média nos meses mais frios por volta de $18^{\circ} \mathrm{C}$, considerado $A w$, na classificação de Koeppen, (COSTA, 2011). 
A cidade de Ituiutaba fica à margem esquerda do rio Tijuco ao Norte, a área do Córrego Buritizal se encontra localizada na porção sul do município de Ituiutaba, MG. Está é uma área que vem sendo ocupada nos últimos anos (Figura 3).

A partir dos campos realizados na Vereda Buritizal constatou-se que ainda há espécies de buritis (Maurítias flexuosas), no entanto, a área vem sofrendo frequente processo de recuo de cabeceira que já sofreram reparo da prefeitura no passado, atualmente foi instalado dentro da vereda construção de tubulação para o lançamento de águas pluviais e a construção de um ginásio escolar nas imediações da nascente, assim como a invasão da área da cabeceira com o plantio de cultura de milho (Figura 4).

Outra descaracterização comprovada é o entalhamento do canal provocado pela instalação das calhas que tem seu fluxo jogado dentro da vereda. Acredita-se que inicialmente este processo tenha entalhado o vale raso. Foi criado dentro da vereda um vale encaixado que drenagem rapidamente o fluxo, o que contraria a caracterização da vereda.

Figura 4: Localização da Cabeceira do Córrego Buritizal com o Ginásio e a via recém instalada para acesso ao bairro Baduy.

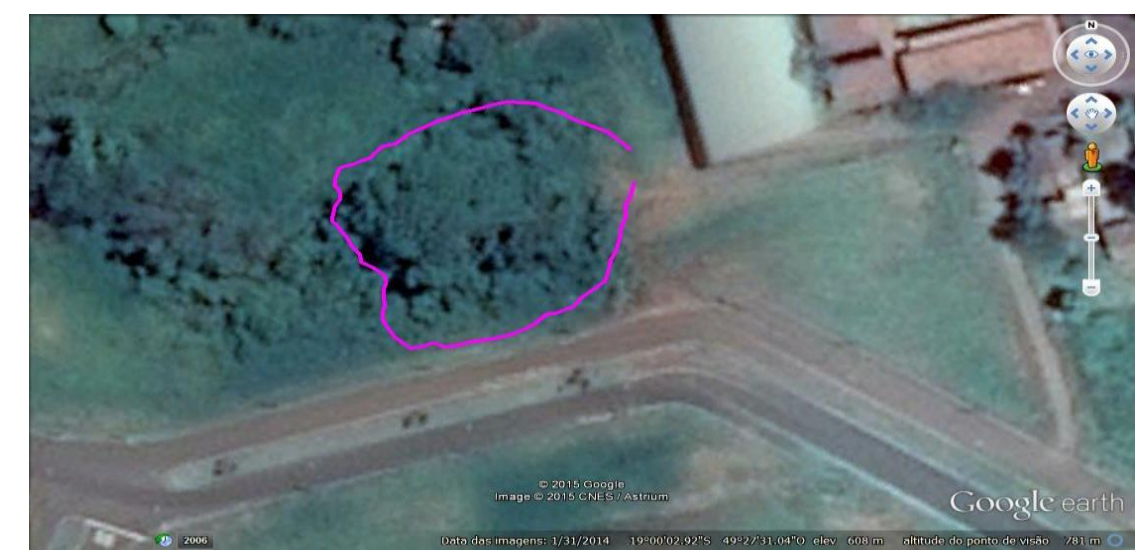

Fonte: Google Earth com pontos coletados em campo.

A nascente é considera uma área de proteção ambiental como previsto na lei do Novo Código Florestal e também na resolução CONAMA/2002, definindo também as áreas de nascente, veredas e as Áreas de Proteção Permanentes (APPs). Novo Código Florestal, 2012, descreve o seguinte sobre APPs e Veredas:

"Art. 4․․ Considera-se Área de Preservação Permanente, em zonas rurais ou urbanas, para os efeitos desta Lei. XI - em veredas, a faixa marginal, em projeção horizontal, com largura mínima de 50 (cinquenta) metros, a partir 
do espaço permanentemente brejoso e encharcado. " (Redação dada pela Lei no 12.727/2012).

Na Resolução da CONAMA no 303 de 20 de março de 2002, define da seguinte maneira "nascente" e sua área de proteção, no artigo $2^{\circ}$ nascente ou olho d’água local onde aflora naturalmente, mesmo que de forma intermitente, a água subterrânea; Art. 3o - Constitui Área de Preservação Permanente a área situada - ao redor de nascente ou olho d’água, ainda que intermitente, com raio mínimo de cinquenta metros de tal forma que proteja, em cada caso, a bacia hidrográfica contribuinte.

Entretanto a vereda Buritizal tem sofrido varias intervenções tanto da iniciativa privada, como o loteamento Gerson Baduy, e as obras públicas de canalização das águas pluviais, que estão sendo lançadas no leito da cabeceira do córrego, ocasionando o aprofundamento do leito, como também o arraste e contaminação do mesmo com lixo domestico e erosão das laterais da do canal escavado. Neste local pode-se observar as manilhas de lançamento de águas pluviais, como podemos ver nas fotos tiradas no local durante 3 (três) meses, registrando a evolução dos problemas gerados pelo lançamento das águas na cabeceira do córrego (Figura 5 e 6).

Nestas figuras 5 e 6 estão em destaque os principais impactos ocorridos com as obras realizadas com lançamento das águas sem qualquer controle. Pode-se observa a erosão das laterais das vertentes com o acumulo de lixo e entulho, e terra colocada para servir de base para a obra. Em 11/12/2014 o volume de águas mostra a capacidade de transporte de material detrítico contendo cascalhos, restos de manilhas, e outros materiais (restos de construção) empregado como forma de preencher a antiga erosão que avançava em direção ao ginásio. No dia 01/12/2014 o material detrítico arrastado está exposto. O que mais se destaca nestas fotos é o grau de entalhamento do canal em uma área de vereda. Esta escavação ocorre em uma área que no passado o lençol freático aflorava. A figura 7 mostra que as manilhas foram desterradas e ficaram expostas depois das chuvas. Esta situação foi reparada alguns meses depois pela prefeitura. 


\section{Periódica Eletrânica

Figura 5: Galerias de aguas pluviais 12/11/2014 e 01/12/2014.

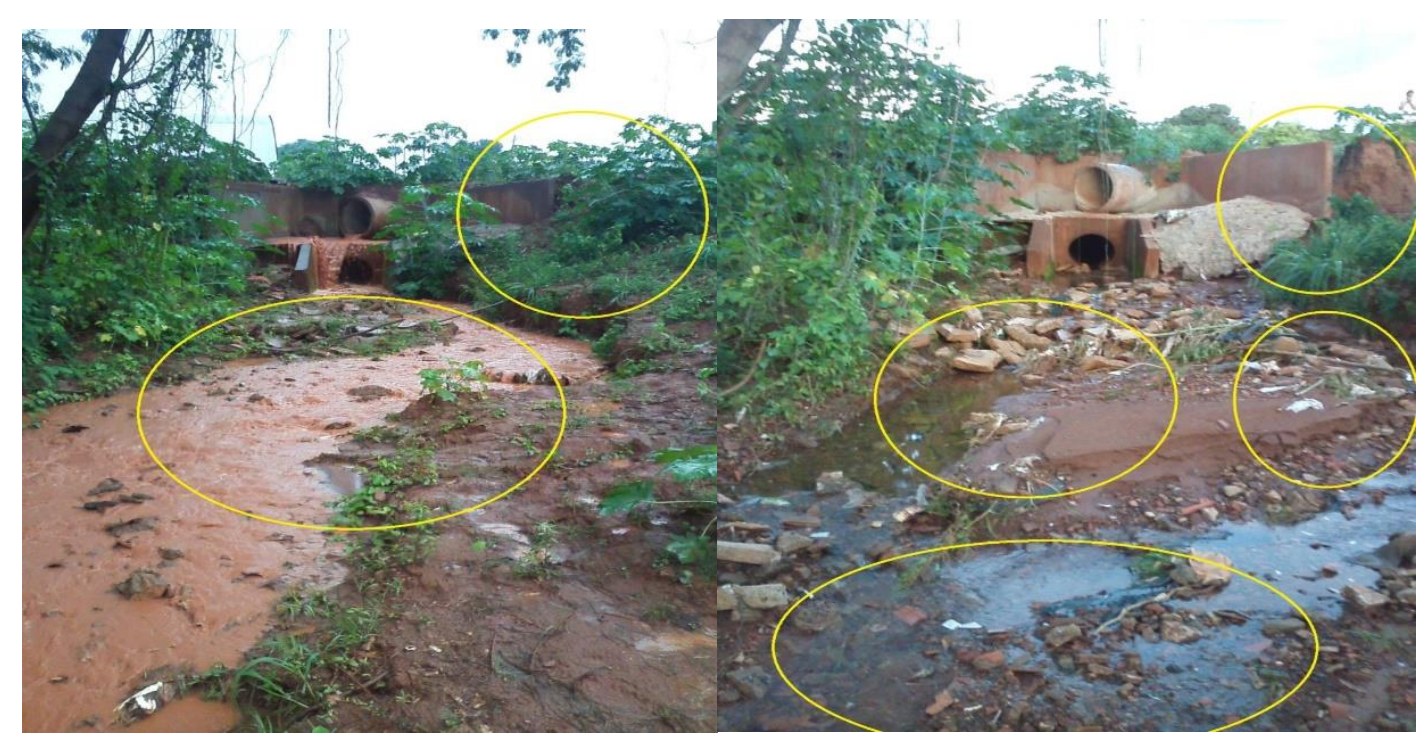

Fonte: Batista, B.H.S

Figura 6: Galerias de águas pluviais 28/01/2015

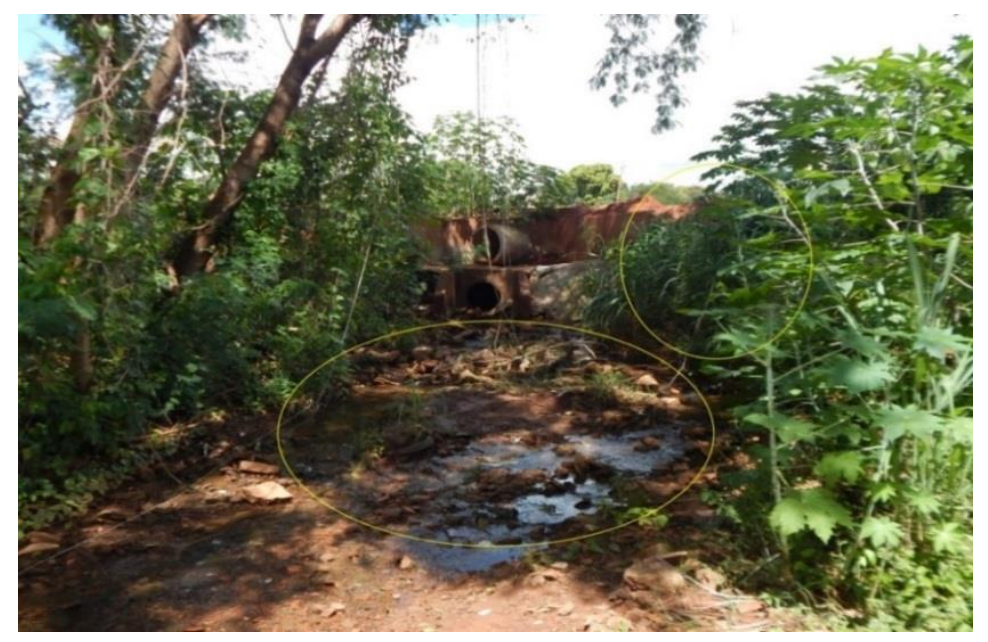

Fonte: Batista, B.H.S

Não foi registrada qualquer obra de contenção do solo, apenas a reposição e uma compactação utilizando o próprio trator que realizou o aterramento.

A preocupação com a drenagem pluvial nas áreas urbanas não é recente onde as águas pluviais são direcionadas a córregos e rios urbanos para evitar a erosão das estruturas urbanas, tem como função direcionar a água a locais mais baixos para evitar sua estagnação, realizando de várias maneiras durante a 


\section{Periádica Eletrânica

evolução das cidades como ressaltam Mascaró e Yoshinaga (2005) esta preocupação não é nova, a declividade longitudinal evita a estagnação das águas.

Figura 8 - Manilha lançando água na cabeceira do Córrego Buritizal

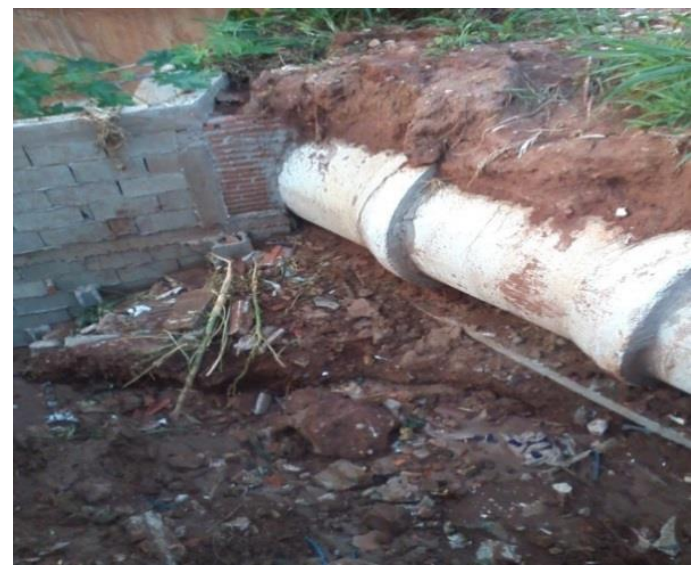

Fonte: Batista, B.H.S

Com essa importância foi se realizado um estudo sobre o perfil longitudinal a fim de se gerar uma imagem sobre a declividade dentro da cabeceira de drenagem, para o reconhecimento do meio físico em que esta está inserida, para se estabelecer os potenciais naturais e antrópicas de degradação da bacia hidrográfica, (BELTRAME 1994).

As manilhas de águas pluviais (Figura 9) despejam o fluxo de água lançando diretamente no córrego que vem em forma quase que retilínea, gerando um potencial destrutivo de escavação do leito do córrego, que se encontra sem escada dissipatória de energia sem qualquer barreira ou quebra de força.

Observando e registrando, se percebeu que houve o rebaixamento e o aumento do fluxo de água na cabeceira e a retirada da vegetação natural para as obras de infraestrutura e também para o cultivo em área urbana, ocorrendo uma erosão acentuada em toda área da cabeceira. Christofoletti (1981) aponta as duas forças que influem sobre os canais abertos e Suguio e Bigarella (1979) falam sobre os efeitos da alteração do fluxo hidráulico:

\footnotetext{
"Qualquer alteração do fluxo (RH), da declividade (S), altera a velocidade das águas, e consequentemente as condições e transporte, deposição e erosão. Um decréscimo no valor numérico da declividade ou no raio hidráulico, ou um aumento do número de Manning (rugosidade) ocasiona um decréscimo na velocidade e portanto, parte da carga é depositada. De
} 
maneira análoga, condições opostas aumentam a capacidade de transporte do rio." (SUGUIO; BIGARELLA, 1979).

Figura 9: Perfil longitudinal do Córrego Buritizal.

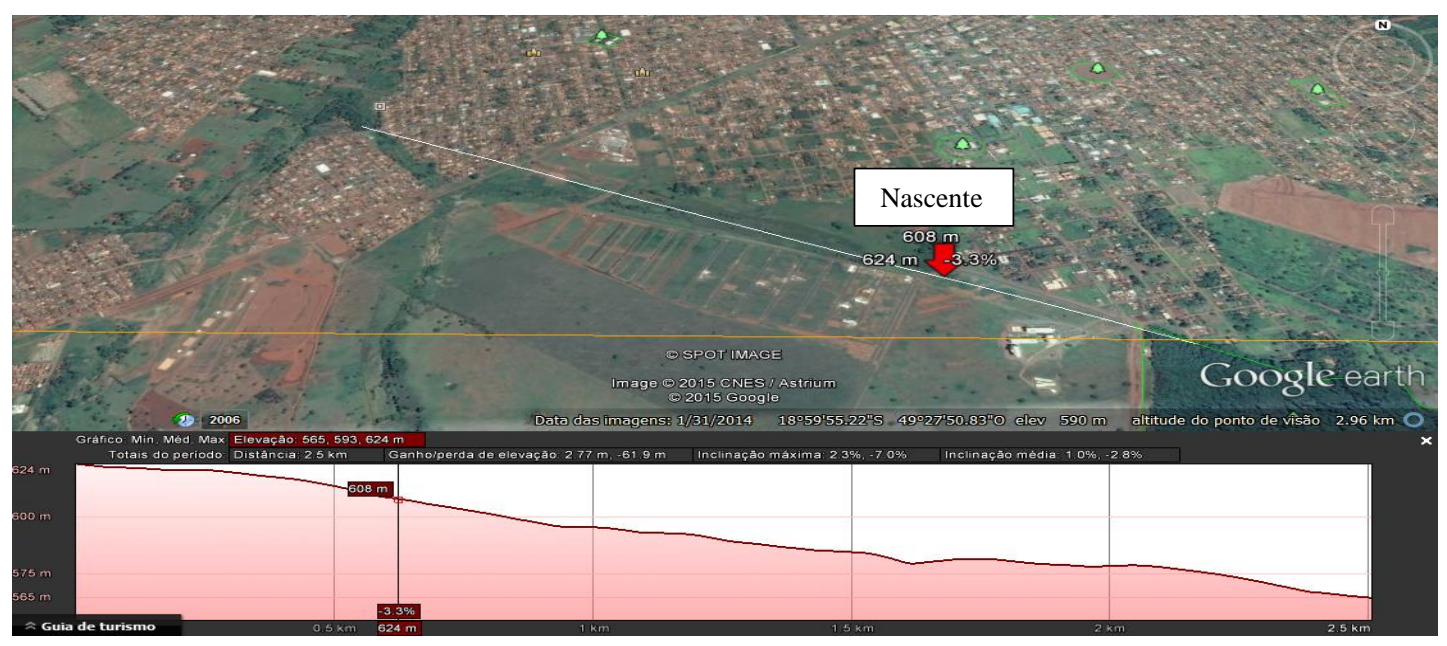

Fonte: Google Earth.

Com isso consegue identificar que com o lançamento de um fluxo não natural de água na cabeceira, aumenta o processo de transporte do córrego e o seu poder de erosão, entretanto esse poder de erosão é fornecido ao córrego apenas na época das chuvas que se dá principalmente no verão, como aponta Mendes e Queiroz (2011), a localização geográfica de Ituiutaba - MG, induz a um regime tropical "com chuvas concentradas no verão, estiagem no inverno outono e primavera, estação de transição. Juntas, essas estações totalizam uma media pluviométrica anual de $1432 \mathrm{~mm}$ em Ituiutaba, sendo $1222 \mathrm{~mm}$ (85\%) concentrados no primeiro e ultimo trimestre do ano. No outro extremo, estão os meses de abril a setembro, que totalizam apenas $210,8 \mathrm{~mm}$ ou seja $15 \%$.

Figura 10: Erosão na Cabeceira do Córrego Buritizal 12/11/2014, 01/12/2014 e 28/01/2015. 


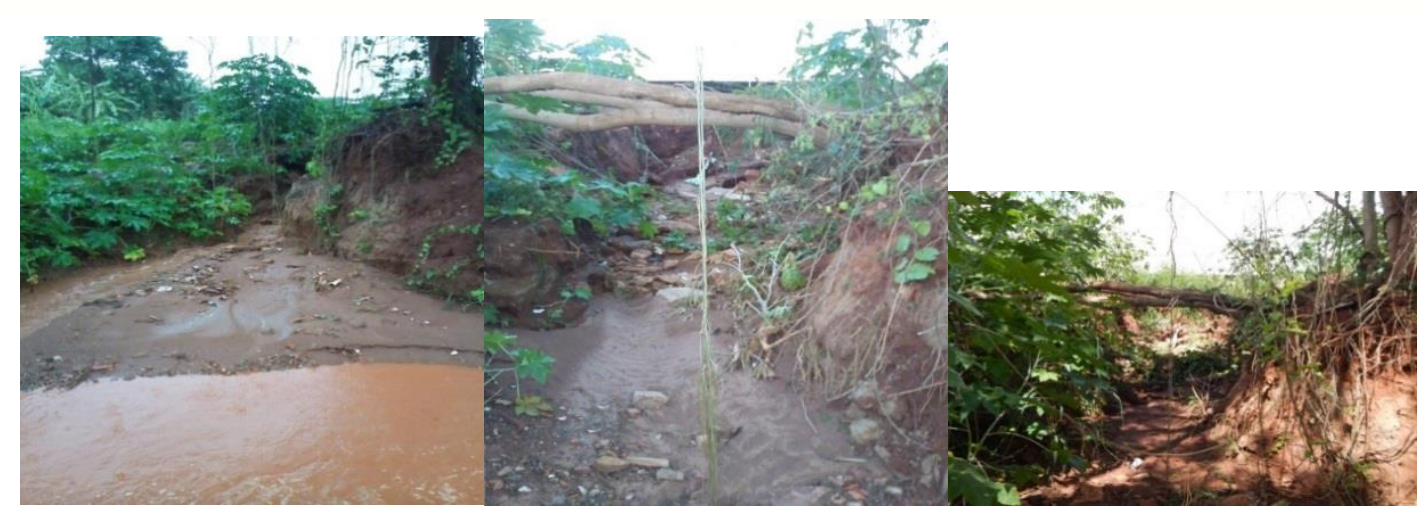

Fonte: BATISTA, B.H.S.

Tendo em vista a importância de se conhecer todas as dinâmicas que ocorrem sobre o meio natural, outro conhecimento prévio que deveria ser levado em consideração e a do escoamento superficial, para a realização do projeto de canalização e lançamento das águas pluviais nos córregos, apontado por Pruski, et.al. (2004).

Para este projeto não foi considerado o escoamento superficial $e$ precipitação média anual de Ituiutaba, uma vez que a obra e seu entorno estão em constante processo de erosão e escavamento em direção a montante, ocasionando ravinas e sucos, como registrados abaixo em uma sequencia de fotos de evolução do problema.

\section{CONSIDERAÇÕES}

Este ensaio teve como o intuito de mostrar alguns problemas ocorrentes nas principais cidades brasileiras, entretanto muitas dessas já sofrem com a falta de água, em função da má gestão das aguas, simplesmente por não entenderem que a rede hidrográfica é um patrimônio natural que precisa ser compreendido para que cumpra sua função em meio social.

E os córregos e rios urbanos menores são os principais atingidos por processos de degradação e antropização, uma vez que estes não são muito considerados i por seu volume de agua, por não ter beleza cênica considerada ou utilizada pelo turismo local.

Com isso o descaso por parte da população e poder público cresce a cada dia, passando assim por cima das legislações, ou mesmo abrindo-se brechas para 


\section{Periádica Eletranica

implantação de obras publicas e privadas em áreas que estão sobre regimes de preservação ambiental permanente.

Este fato leva a se refletir o novo conceito e comprometimento das cidades sobre as áreas de preservação, principalmente sobre o cerrado, que já vem perdendo suas características e se tornando um ambiente antropizado, artificializado.

\section{REFERÊNCIAS}

BELTRAME, A.V. Diagnóstico do meio físico de bacias hidrográficas: modelo e aplicação. Florianópolis: UFSC, 1994.

BIGARELLA, J.J.; SUGUIO, K. Ambiente Fluvial. Curitiba: UFP, 1979.

CHRISTOFOLETTI, A. Geomorfologia fluvial. São Paulo: Edgard Blucher, 1981.

CONGRESSO NACIONAL. LEI № 12.651, DE 25 DE MAIO DE 2012. Brasília, 2012.

COSTA, R. A. Análise Biogeográfica do Parque Municipal do Goiabal em Ituiutaba. - MG.

Presidente Prudente: Caderno Prudentino de Geografia, n.33, v.1, p.68-83, jan./jul.2011.

FERREIRA, I.M. Paisagens do Cerrado: Aspectos Conceituais sobre Vereda. IX Simpósio Nacional do Cerrado, Brasília, 2008.

FERREIRA, I. M. Bioma Cerrado: caracterização dos subsistemas de vereda EREGEO - Encontro Regional de Geografia. Novas territorialidades - integração e redefinição regional. Porto Nacional, julho de 2005.

FLORENZANO, T. G. Geomorfologia: conceitos e tecnologias atuais. São Paulo: Oficina de Textos, 2008.

GUERRA, A. J. T.; CUNHA, S. B. da. (Org.) Geomorfologia: uma atualização de bases e conceitos. 3. ed. Rio de Janeiro: Bertrand Brasil, 1998.

GUERRA A. J. T.; CUNHA, S. B. da. (Org.) Geomorfologia: Exercícios, Técnicas e Aplicações. 3. ed. Rio de Janeiro: Bertrand Brasil, 2002.

GUERRA, A.J.T; CUNHA, S.B. (Org.). Impactos Ambientais Urbanos no Brasil. Rio de Janeiro: Bertrand Brasil, 2013.

LIMA, S. C. A preservação das veredas para manutenção do equilíbrio hidrológico dos cursos d'água. In: ENCONTRO NACIONAL DE ESTUDOS SOBRE O MEIO AMBIENTE, 3., 1991, Londrina. Anais... Londrina: UEL/NEMA, 1991. p. 204-218. 
MASCARÓ, J.L.; YOSHINAGA, M. Infra-estrutura urbana. Porto Alegre: Masquatro, 2005.

PORTUGUEZ, A.P; MOURA, G.G.; COSTA, R.A. (Org.). Geografia do Brasil Central: Enfoques teóricos e particularidades regionais. Uberlândia: Assis Editora, 2011.

PRUSKI, F.F.; BRANDÃO, V.S., SILVA, D.D. Escoamento superficial. 2.ed. Viçosa: UFV, 2004.

ROSS, Jurandy L. Sanches. O registro cartográfico dos fatos geomórficos e a questão da taxonomia do relevo. Revista do Departamento de Geografia, FFLCH-USP, São Paulo, v. 6 p. 1729, 1992.

THOMAS H. Para entender a Terra. 4. ed. Tradução. Porto Alegre: Bookman, 2006. 